\title{
Increasing the thermal efficiency of boiler plant
}

\author{
Evgeniy Uyanchinov ${ }^{1, *}$, and Igor Razov ${ }^{2}$ \\ ${ }^{1}$ National Research Tomsk Polytechnic University, 634050 Tomsk, Russia \\ ${ }^{2}$ Tyumen industrial University, 625000 Tyumen, Russia
}

\begin{abstract}
The thermal efficiency increase of boiler plant is actual task of scientific and technical researches. The optimization of boiler operating conditions is task complex, which determine by most probable average load of boiler, operating time and characteristics of the auxiliary equipment. The work purpose - the determination of thermodynamic efficiency increase ways for boiler plant with a gas-tube boiler. The tasks, solved at the research are the calculation of heat and fuel demand, the exergetic analysis of boilerhouse and heat network equipment, the determination of hydraulic losses and exergy losses due to restriction. The calculation was shown that the exergy destruction can be reduced by $2.39 \%$ due to excess air reducing to $10 \%$; in addition the oxygen enrichment of air can be used that leads to reducing of the exergy destruction rate. The processes of carbon deposition from the side of flame and processes of scale formation on the water side leads to about $4.58 \%$ losses of fuel energy at gas-tube boiler. It was shown that the exergy losses may be reduced by $2.31 \%$ due to stack gases temperature reducing to $148^{\circ} \mathrm{C}$.
\end{abstract}

\section{Introduction}

One of the most important actions to efficiency increase of boiler plant is correct choice of capacity and boiler amount for projected heat supply source [1-3]. The optimization of boiler operating conditions is task complex, which determine by most probable average load of boiler, operating time and characteristics of the auxiliary equipment [4-7]. The work purpose - the determination of thermodynamic efficiency increase ways for boiler plant with a gas-tube boiler. The tasks, solved at the research are the calculation of heat and fuel demand, the exergetic analysis of boilerhouse and heat network equipment, the determination of hydraulic losses and exergy losses due to restriction. The work scientific novelty is applying of modern exergetic analysis methods to new object of research - gastube boiler and boilerhouses, equipped this boilers. The work novelty - the known data improvement and addition about research object and topic.

\footnotetext{
* Corresponding author: uyanchinov9576@gmail.com
} 


\section{Method of the research}

The installation variants of boilers with various output were analyzed for determination of boilers amount, installed in the boiler house. The analysis was carried out by developed software package, which allows calculate the technical and economic characteristics of the boiler plant. The input parameters are the fuel and air energy and exergy, the output parameters are the coolant energy and exergy. The identification of exergy destruction allows find the thermal efficiency increase ways. The first propositions about exergy using for economic evaluation of efficiency were proposed by A. Andryushchenko [8, 9], Z. Rant $[10,11]$, J. Shargut $[12,13]$. The influence of air combustion temperature and excess air, the influence of heat losses renewal at the steam generator and influence of stack effluents temperature to the exergy destruction at combustion chamber, steam generator and funnel can be modelled by modern software products.

\section{Results and discussion}

The calculations (Table 1) were shown that the thermal efficiency, the exergy efficiency and the boiler energy are accordingly $74.16 \%, 31.55 \%$ and $0.43 \%$. The thermal efficiency is sufficiently low due to excessive heat funnel and steam generator losses, just as conservation index has a low quality due to the very low coolant exergy/energy ratio, which does not exceed 0.5. It was established that stack effluents have $22.59 \%$ of fuel energy due to high temperature of boiler outlet, although only a part of this loss can be recovered [14].

Table 1. The initial data for economic evaluation of operating.

\begin{tabular}{|c|c|c|}
\hline Parameter & Value & Unit of measurement \\
\hline Natural gas & 4.12 to 7.29 & $\mathrm{rub} / \mathrm{m}^{3}$ \\
\hline Cost of energy unit & 0.0003 & $\mathrm{rub} / \mathrm{kJ}$ \\
\hline Cost of exergy unit & 0.0003 & $\mathrm{rub} / \mathrm{kJ}$ \\
\hline Electricity & 4.5 & $\mathrm{rub} /(\mathrm{kW} \cdot \mathrm{hour})$ \\
\hline Operating hours & 8 & thousand hour/year \\
\hline
\end{tabular}

It was found that the loss with heat of stack gases, which is the main source of energy losses and leads to $82.3 \%$ of total heat losses due to very high stack effluents temperature at funnel, is only $8.7 \%$ of total exergy destruction.

The operating costs during operation of boiler house was evaluated and aspects of fuel exergy economy, such as fuel cost, boiler water preparation cost, boiler water pumping cost and cost of air supplying for combustion, were identified in this work. The thermal and economic analysis of gas-tube boiler, considered the current and optimal operating costs, was made. It was established that the heat and exergy efficiency of researched boiler was not optimal due to excessive losses at combustion chamber, steam generator and funnel. The operating costs were also high due to fast exergy destruction. The approach of intrinsically value, which corresponds to current boiler operation, and marginal number of cost, which corresponds to optimal operation, lead to annualized savings at the $5,561,214$ million rubles. Also, the modelling has shown that the optimal values of air combustion temperature, excess air and stack effluents temperature are accordingly $135{ }^{\circ} \mathrm{C}$, $10 \%$ and $150{ }^{\circ} \mathrm{C}$. The optimization of air combustion temperature, excess air, recuperation in convectional heating surfaces and temperature of stack gases was made to increase boiler efficiency.

The result of parametric optimization was the reducing the required fuel exergy during the boiler operation $(5,648.2 \mathrm{~kW})$ by $10.66 \%$ in comparison with the initial state 
$(6,322.3 \mathrm{~kW})$. The losses with thermodynamic irreversibility were also reduced by $3.9 \%$ and $1.3 \%$ at the combustion chamber and funnel accordingly.

The comparison of researched and optimized boilers is shown in the table 2. The optimization enables increasing the thermal efficiency by $4.91 \%$ that lead to increase of exergy efficiency by $3.62 \%$, the economy of fuel costs and electricity amounts to $10.66 \%$ and $10.9 \%$ accordingly. Thus, the annualized savings amounts to 5561214 million rubles those equivalents to $11.8 \%$ increase of net efficiency.

Table 2. The parametric optimization based on thermoeconomic theory.

\begin{tabular}{|c|c|c|c|}
\hline Parameter & Unit of measurement & $\begin{array}{c}\text { Before } \\
\text { optimization }\end{array}$ & $\begin{array}{c}\text { After } \\
\text { optimization }\end{array}$ \\
\hline Efficiency & $\%$ & 74.16 & 77.78 \\
\hline Exergy efficiency & $\%$ & 31.55 & 36.25 \\
\hline Fuel costs & million rubles/gigacalorie & 790.76 & 706.61 \\
\hline Boiler water preparation cost & rubles /gigacalorie & 302.064 & 302.064 \\
\hline Boiler water pumping cost & rubles /gigacalorie & 8.9 & 8.9 \\
\hline Cost of air supplying & rubles /gigacalorie & 23.89 & 20.17 \\
\hline Total of operating costs & rubles /gigacalorie & 1125.72 & 1037.80 \\
\hline
\end{tabular}

\section{Conclusions}

It was established that the exergy destruction can be reduced by $2.39 \%$ due to excess air reducing to $10 \%$. In addition, the rate of exergy destruction can be reduced by oxygen enrichment of air. The steam generator has a low energy transfer to the final product due to a very low coolant exergy/energy ratio. Consequently, only small part of the exergy destruction may be removable. It was established that the processes of carbon deposition from the side of flame and processes of scale formation on the water side is cause of heat energy loss to $4.58 \%$ at gas-tube boiler. And then, exergy losses may be reduced by $2.31 \%$ due to stack gases temperature reducing to $148{ }^{\circ} \mathrm{C}$. The further decrease of stack gases temperature does not allowed; because it leads to low-temperature corrosion in the boiler pipes and funnel lining. The modelling shows that exergy destruction of steam generator may be additionally reduced by cleaning and proper maintenance.

\section{References}

1. E. L. Paley, The normative requirements and practical recommendations at the boilerhouses design. Reference and practical book (Peter, St. Petersburg, 2014)

2. R. B. Tabakaev, A. V. Kazakov, A. S. Zavorin, Solid Fuel Chemistry 49, 267 (2015)

3. S. A. Khaustov, A. S. Zavorin, K. V. Buvakov, L. D. Kudryashova, A. V. Tshelkunova, EPJ Web Conf., 82, 01041 (2015)

4. S. A. Khaustov, A. S. Zavorin, K. V. Buvakov, V. A. Sheikin, EPJ Web Conf., 82, 01039 (2015)

5. Khaustov S. A., Belousova Y. A., Buvakov K. V., Dolgih A. Y., Kulesh R. N. Proc. of 11th International Forum on Strategic Technology (IFOST - 2016), 2, 548 (2016)

6. A. V. Kazakov, R. B. Tabakaev, P. Y. Novoseltsev, A. V. Astafev, A.V., MATEC Web Conf., 19, 01014 (2014)

7. Sannikov D. I. About amount of the boilers for designed boiler plant [Electronic source] // RosTeplo - Access: http://www.rosteplo.ru/Tech_stat/stat_shablon. php?id=2921 
8. A. I. Andryushchenko, The technical working capacity of thermodynamical systems (Saratov institute of Automobile and Road, Saratov, 1956)

9. A. I. Andryushchenko. The thermodynamical calculations of optimal parameters on thermal stations (Gosenergoizdat, Moscow, 1963)

10. Z. Rant, Forsch. Ing.-Wes., 22, 212 (1956)

11. Z. Rant, BWK, 12, 297 (1960)

12. J. Szargut, Archiwun Hutnictwa, 6, 23 (1961)

13. J. Szargut, Energetyka Przemyslowa, 9, 73 (1961)

14. N. Tobish., M. Zafar., M. Rustam., S. H. Javed., N. Feroze., M. Kazimi., Jurnal of Pakistan Institute of Chemical Engineers., (2014) 